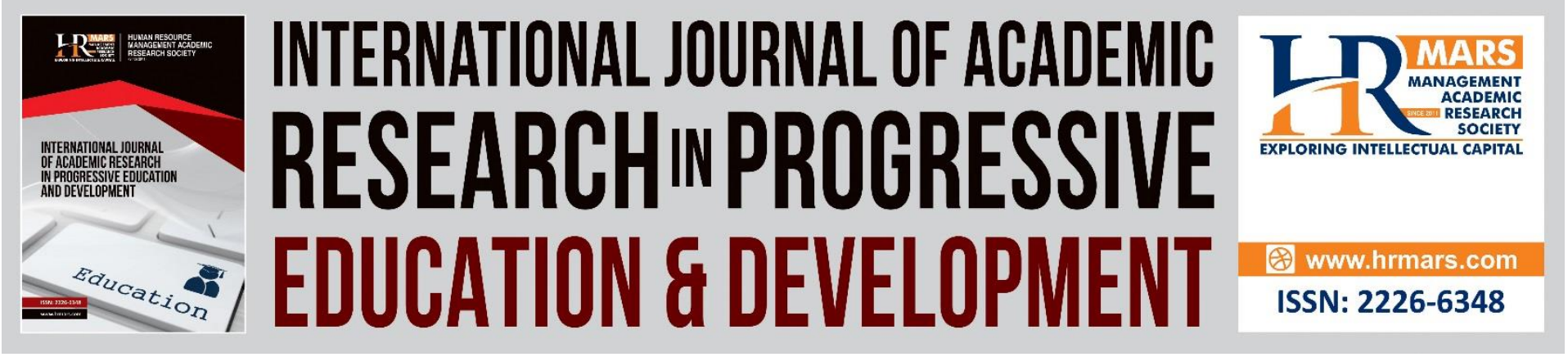

\title{
Directing the Enigma of Quranic Words According to Ibn Qutaybah and Al-Far
}

Mohamed Fathy Mohamed Abdelgelil, Ammar Kamal Ibrahim Othman, Mukhamad Hadi Musolin Subagio, Reda Owis Hassan Serour, Ahmad Fauzi Hassan, Mahmoud Fathy Mohamed Abdelgalil Osman

To Link this Article: http://dx.doi.org/10.6007/IJARPED/v10-i3/11004

DOI:10.6007/IJARPED/v10-i3/11004

Received: 05 July 2021, Revised: 12 August 2021, Accepted: 29 August 2021

Published Online: 17 September 2021

In-Text Citation: (Abdelgelil et al., 2021)

To Cite this Article: Abdelgelil, M. F. M., Othman, A. K. I., Subagio, M. H. M., Serour, R. O. H., Hassan, A. F., \& Osman, M. F. M. A. (2021). Directing the Enigma of Quranic Words According to Ibn Qutaybah and Al-Far. International Journal of Academic Research in Progressive Education and Development, 10(3), 427-434.

Copyright: (C) 2021 The Author(s)

Published by Human Resource Management Academic Research Society (www.hrmars.com)

This article is published under the Creative Commons Attribution (CC BY 4.0) license. Anyone may reproduce, distribute, translate and create derivative works of this article (for both commercial and non-commercial purposes), subject to full attribution to the original publication and authors. The full terms of this license may be seen at: http://creativecommons.org/licences/by/4.0/legalcode

Vol. 10(3) 2021, Pg. 427 - 434

http://hrmars.com/index.php/pages/detail/IJARPED

JOURNAL HOMEPAGE

Full Terms \& Conditions of access and use can be found at http://hrmars.com/index.php/pages/detail/publication-ethics 


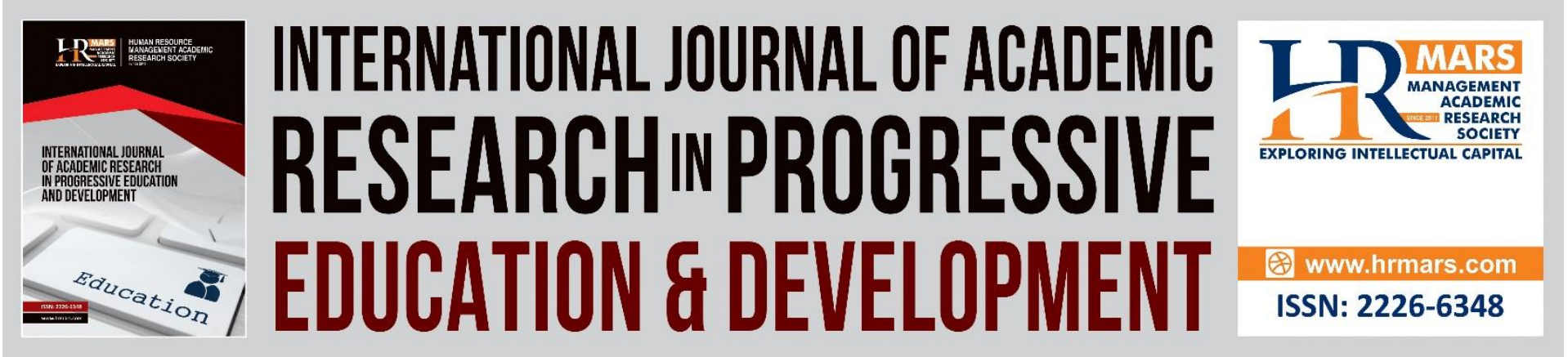

\title{
Directing the Enigma of Quranic Words According to Ibn Qutaybah and Al-Far'
}

\author{
${ }^{1}$ Mohamed Fathy Mohamed Abdelgelil, ${ }^{1}$ Ammar Kamal Ibrahim \\ Othman, ${ }^{2}$ Mukhamad Hadi Musolin Subagio, ${ }^{2}$ Reda Owis \\ Hassan Serour, ${ }^{1}$ Ahmad Fauzi Hassan, ${ }^{3}$ Mahmoud Fathy \\ Mohamed Abdelgalil Osman \\ ${ }^{1}$ Faculty of Islamic Contemporary Studies (FKI), Sultan Zainal Abidin University (UniSZA), \\ 21300, Terengganu, Malaysia, ${ }^{2}$ Sultan Abdul Halim Mu'adzam Shah International Islamic \\ University, (UniSHAMS), Malaysia, ${ }^{3}$ Sharjah Islamic Affairs, The United Arab Emirates (UAE) \\ Email: mfathy@unisza.edu.my
}

\begin{abstract}
The Qur'anic enigma may be taken by some as an excuse to defame the Holy Qur'an, but perhaps this may lead to defaming the true Islamic religion as a whole, and herein lies the problem of the research, which aims to trace some Qur'anic terms in which the ambiguity is imagined. Then remove it, and the role of Ibn Qutayba and Al-Fara regarding that. The research was based on the analytical approach to trace the Qur'anic verses concerned with the study and turned them to the grammatical and interpretive rules to know their meanings that eliminates the delusional disorder, and it appeared from the results that there is no contradiction in the Holy Qur'an, and the people of interpretation also relied on eliminating the illusion of confusion on the Arabs' use of Arabic words. In addition that, inadequate understanding and lack of knowledge is one of the biggest reasons that leads to confusion in the understanding of the Holy Qur'an, and the sayings of the ancestors have an effective role in revealing the problematic meanings that constitute some verses of the Qur'an. The application of the abstract mind is one of the most paths that lead to saying in the Qur'an without knowledge, and accusing it of mistake.
\end{abstract}

Keywords: Interpreters, Followers, the Arabic Language, the Qur'anic Enigma, Disturbance.

\section{Introduction}

The interpreters directed the enigma with interpretation and clarification of the meaning; such as directing the enigma of syntax by meaning and extracting the effect of interpretation in the syntax, directing what is related to the problems contained in the styles of the Qur'an by meaning, and extracting the effect of interpretation in rhetoric. We can present what is related to the illusion of the difference and contradiction between the verses and their meanings, as well as what is related to the confusion in the meanings of some verses in their places, and solving these problems by explaining what is meant, and clarifying the meaning. 
In addition to combining the meanings of the verses in a way that eliminates illusion and solves the problem, and before going through the article, we note that the Holy Qur'an in general, and Qur'anic readings and interpretation in particular, have been served a great service by researchers with writings, research and scientific papers, whether it is through publication in scientific journals of various classifications, international conferences, or otherwise.

\section{Preface}

The origin of the problem with the verses of the Qur'an is that it is in the meaning, style, or syntax. Under the meaning is what is enigmatic in the meanings of the words, what is enigmatic in the meaning of a single verse, and the relationship of proportionality between the meanings of the paragraphs. Under it also is the illusion of difference and contradiction, except that it is often between two positions in the Qur'an, and the interpreters have clarified everything related to that, but what concerns us here is directing the enigmatic meaning of the verse and its concept by clarifying the correct meaning that is intended in the verse, which is in the following points.

\section{1- $\quad$ Enigma of Words}

This type of vocabulary is related to the chapter on allegory and metaphors, and Ibn Qutayba took care of clarifying it in its places, and among this is the use of Qur'an to some of the Qur'anic vocabulary with a meaning that is predominant in it, then this vocabulary comes in a context in which its meaning contradicts what is in the majority of the Qur'an. This causes a problem in understanding this word in its context, and clarifying the meaning intended for it in its place is a way to remove the confusion and clarify the purpose, as in the Almighty's saying: "like the example of a rain whose [resulting] plant growth pleases the tillers (كفار); then it dries and you see it turned yellow" (Quran, Al-Hadid: 57/20)The slanderers imagined that what is meant by the (Kofar) "كفار"here is the opposite of the believers, as is the meaning in most of the Qur'an, except that Ibn Qutayba clarified the problem, and indicated that what is meant by the (Kofar) "كفار" here is the word: Tillers (كفار), and the singular is tiller (كافر), he was called a (كافر) because if he casts the seed on the ground, he would conceal it (كفرهار) i.e.: Cover it, and everything you cover you conceal it (كفرته), and from it was said: Someone put on his weapon: If he covered, and from it is said about the night: Covering (كافها (كاته), because it covers everything with its darkness, and this is like the saying of the Almighty: "delighting the sowers so that Allah enrage by them the disbelievers." (Quran, Al-Fath, 48: 29) (Ibn Qutayba, 2002, 52)

The confusion may occur in the meaning of a word that came after another, and they are synonymous in meaning, so the repetition of the same meaning is assumed, which leads to the illusion of confusion in the composition of the Qur'an, the interpreter explains their meaning, and the difference between them, and removes the confusion, as in the Almighty's saying: "And made your sleep for rest" (Quran, An-Naba, 78: 9)Where Ibn Qutayba explained that (سبات) here does not mean sleep, so its meaning is: And we made your sleep a sleep, but (سبات) is rest, i.e.: We made sleep a rest for your body.

\section{2- $\quad$ The Enigma of Meanings in One Verse}

It may be understood from some verses an unintended meaning, which causes a problem, and it may be imagined that there is a contradiction between some verses, and the 
contradiction in reality exists in the understanding of the enigma. So, clarifying the correct meaning in the verse, and clarifying its intended meaning, is what removes the confusion and eliminates what the illusionists have imagined. As in His saying: "Every time their skins are roasted through We will replace them with other skins" (Quran, An-Nisa, 4: 56) as Imam Ahmad mentioned the heretics' confusion with their understanding that what is tormented are the skins that have disobeyed and have been burned, so how does He say: (other skins), and punishes skins that have not sinned? Then he answered this enigma by saying that it does not mean skins other than theirs - as they understood, but that replacing them means: Refurbishing them; Because if their skins are roasted, they will be refurbished by Allah Almighty (Ibn Hanbal, 2010, 60).

\section{3- The Enigma of Proportionality between the Parts of one Verse or One Context}

Among what might be a cause of confusion for some of them is the illusion of contradiction and difference due to the hidden aspect of the relationship between the parts of a single verse in its context, and the lack of proportionality between its parts in the apparent meaning of the Qur'anic text, the explanation of the interpreter of the aspect of the proportionality between the parts of the verse removes the confusion, and clarifies the point, for example, the Almighty's saying: "And if you fear that you will not deal justly with the orphan girls, then marry those that please you of [other] women, two or three or four" (Quran, An-Nisa, 4: 3)As Al-Far'a and Ibn Qutayba in the verse were confused about shifting the talk about orphans' money to talking about marriage.

Then they explained the proportionality between them that when they left the dealing with orphans in embarrassment, Allah Almighty made clear to them that just as you were embarrassed about eating with orphans, and were afraid that you would not treat them justly if you foster care of them, then fear of polygamy, and not being able to treat them justly, then marry two, three, and four and do not go beyond that, that you be unable to do justice (Ibn Qutayba, 2002, 52; Fur, 1990, 1/253).

It was enigmatic for those who suspected the existence of contradiction and difference in terms of the relationship and proportionality between the Almighty's saying: "Allah has made the Ka'bah, the Sacred House, standing for the people and [has sanctified] the sacred months and the sacrificial animals and the garlands [by which they are identified]." And His saying: "That is so you may know that Allah knows what is in the heavens and what is in the earth and that Allah is knowing of all things." (Quran, Al-Ma'idah, 5: 97)As if the two sentences are not related to each other in meaning.

Ibn Qutayba removed this confusion, clarified the intended meaning, and showed the proportionality between the beginning and the end of the verse that the people of the preIslamic era were plundering each other, shedding blood without right, and unjustly taking money. A man asks them to take revenge, so another the his killer is killed, so Allah made the Kaaba the Sacred House and what around it from the Sanctuary, the sacred month, the sacrifices, and the garlands as a support for the people, i.e.: A safe place for them. If a man feared for himself, he would resort to the sanctuary and be safe. When it's one of the sacred months, they would settle in their stores, and they will feel secure about their money and themselves. If people were left in their ignorance, the earth would be corrupted, people were to be annihilated, stranded, and shops were to stop their activities. So, Allah did that because of His knowledge of what is right for them, and so that they know that as He knows what is good for them, that He also knows what is in the heavens and what is on earth from the 
interests of the servants and their facilities, and that He is All-Knowing of everything. (Ibn Qutayba, 2002, 51; al-Tabari, 2000, 9/11; al-Thalabi, 2002, 4/112)

\section{4- The enigma of delusion of conflicting meanings between multiple verses}

The one who spoke most in clarifying the illusion of the difference and contradiction between the meanings of the verses of the Qur'an in the first three centuries is Imam Ahmad in the book attributed to him "The Response to the Heretics and the Jahmiyyah", under the section "Explanation of what the heretics have misled from the similarities of the Qur'an", then Ibn Qutayba came after him in his book "The Interpretation of the Enigma of the Qur'an", under "The Chapter of Contradiction and Difference", in addition to Alfaraa' and his examples.

Some of the verses in the Book of Allah Almighty may have a relationship in the meanings, so some of those who do not know may imagine that there is a difference or contradiction between the meanings of these verses, although each verse of it is specific to a meaning that does not contradict the other verse, so the scholars explained these meanings in a way that pushes an illusion of delusional people, and slander of slanderers, and as an example for what they imagined as a contradiction in the Almighty's saying "And they will approach one another blaming each other."(Quran, As-Saffat, 37: 27), and His saying: "no relationship will there be among them that Day, nor will they ask about one another."(Quran, al-Mu'minun, 23: 101) By affirming the questioning between them in the first verse, and denying it in the second verse.

This enigma was presented by Imam Ahmad and Ibn Qutayba, then they explained what eliminates this illusion of meanings, and its summary is that every verse speaks of a situation without another of the situations of the day of Resurrection, so they do not question in one situation, and they question in another.

Imam Ahmad explained that the people at the second blow, if they rise from the graves, do not question, and do not speak in that place, and if they are held accountable, and entered Paradise and Hell, some of them turn to each other questioning (Ibn Hanbal, 2010, 65).

And Ibn Qutayba explained that if a single blow is blown in the Horn, the ties of relationship will be severed, the lineages will be null and they will be busy with their selves and distracted from questioning, "and whoever is in the heavens and whoever is on the earth will fall dead except whom Allah wills." (Quran, Az-Zumar, 39: 68)Then it will be blown again they will stand up looking،"And they will approach one another blaming each other."(Quran, As-Saffat, 37: 27) (Ibn Qutayba, 2002, 52; Al-Fara, 1990, 1/253).

Although Ibn Qutayba's guidance differs from that of Imam Ahmad, the guidance eliminates the illusory contradiction between the verses, and that they are questioning in one situation and not another.

They also imagined that there is a discrepancy and a contradiction between the Almighty's saying: "This is a Day they will not speak," (Quran, Al-Mursalat, 77: 35), and His saying: (Then indeed you, on the Day of Resurrection, before your Lord, will dispute.) (Quran, Az-Zumar, 39: 31).

This problem was presented by Imam Ahmad and Ibn Qutayba, and his answer is the same as the previous one, and its summary: They speak in situations, and do not speak in others.

Imam Ahmad explained that they do not speak the creatures are first resurrected for over a period of sixty years, and they are not given permission to apologize, so they apologize, then they are given permission to speak and then they speak. (Ibn Hanbal, 2010, 61). 
And Ibn Qutayba explained that they quarrel and the oppressed curse the oppressors, in that case they quarrel, and if retribution takes place and the sentence is proven, it is said to them: Do not quarrel, do not speak, and do not apologize, for that is of no use to you, and is not beneficial to you, so they will be despised. A man came to Ikrima and said: Did you notice the words of Allah Almighty: (This is a Day they will not speak,) (Quran, Al-Mursalat, 77: 35), and His saying: (Then indeed you, on the Day of Resurrection, before your Lord, will dispute.) (Quran, Az-Zumar, 39: 31) He said: These are situations. One of them is: They spoke and quarreled, then Allah sealed their mouths, so that their hands and feet speak, then at that time they would not speak. (Ibn Qutaiba, 2002, 46; Abd al-Razzaq, 1999, 1/460).

Ibn Qutayba cited a problem with which the slanderers slandered the primacy of creation between heaven and earth, arguing with evidence that proves to the extent of their ignorance that the heavens were created first, and other evidences that prove that the earth was created first, and they claim the contradiction in that, as they understood from the Almighty's saying: Say, "Do you indeed disbelieve in He who created the earth in two days and attribute to Him equals? That is the Lord of the worlds * And He placed on the earth firmly set mountains over its surface, and He blessed it and determined therein its [creatures'] sustenance in four days without distinction - for [the information] of those who ask.* Then He directed Himself to the heaven while it was smoke and said to it and to the earth, "Come [into being], willingly or by compulsion." They said, "We have come willingly." (Quran, Fussilat, 41: 9-11), these verses indicate that He created the earth before the heavens.

They understood from the verse: "Are you a more difficult creation or is the heaven? Allah constructed it * He raised its ceiling and proportioned it * And He darkened its night and extracted its brightness * and after that He spread the earth." (The Qur'an, Al-Naziat, 79: 2730), this verse indicates that He created the heavens before the earth.

Then he answered their enigma, and eliminated the contradictions in their minds, that the Book of Allah does not care about distortion of the ignorant, and the mistakes of interpreters, and he combined the verses that the slanderer would have find a link and a saying if Allah would have said: And the earth after that he created it, or initiated it, or established it, but He said: (He spread the earth), So He began the creation of the earth as in the first verse in two days, then He created the heavens and they were smoke in two days, then He spread out after that the earth, i.e.: He spread it and extended it, and it was a combined hill, He made them firm with the mountains, and the vegetation grew therein in two days, so those are six days, for [the information] of those who ask (Ibn Qutayba, 2002, 46).

The verses in which the slanderers imagine contradictions are many, and most of what they contain needs clarification and interpretation, and the removal of their enigma is by combining their meanings and directing them.

Much of what the slanderers have been slandering of is only for those whose ignorance is great, and his understanding of the language of the Qur'an is weak, and did not want to contemplate the Book of Allah Almighty, nor to search in its meanings, but his purpose is to slander and distort, even with matters that do not deserve attention.

Many of what has been enigmatic in the Book of Allah Almighty by those of corrupt interpretations is from the point of view of presenting the verses of the Qur'an to their minds, making them a rule over its texts, and following their whims, then twisting the texts by interpreting them according to their approaches that they followed. 
DEVELOPMENT

Vol. 10, No. 3, 2021, E-ISSN: 2226-6348 @ 2021 HRMARS

\section{Conclusion}

After we went through this blessed Qur'anic research, these results appeared to us:

1. There is no contradiction in the Holy Quran.

2. To push back the illusion of confusion, the scholars relied on the Arabs' use of Arabic words.

3. Poor understanding and lack of knowledge is one of the biggest reasons that lead to confusion in understanding the Holy Qur'an

4. The sayings of the ancestors have an effective role in revealing the meanings of some verses of the Qur'an.

5. Implementing the abstract mind is one of the most common ways that leads to interpreting the Qur'an without knowledge, and accusing it of being wrong.

\section{References}

Al-Quran Al-Karim.

Aabdulrazzaq, A. A. (1999). Tafsir Aabdulrazzaq. Tahqiq: Dr. Mahmud Muhammad 'Abduh. Beirut: Dar Alkutub Al'Elmiyah.

Abdelgelil, M. F. M. (2020). Grammarians' Critique of Qur'anic Qira'at. International Journal of Academic Research in Business and Social Sciences, 10(11), 1225-1231.

Abdelgelil, M. F. M. (2020). Solving the Quranic Issues with Quranic Qira'at, International Journal of Academic Research in Business and Social Sciences, 10(12), 36-42.

Abdelgelil, M. F. M., Al-Janayni, M. U., Baru, R., Hamzah, M. S., Razali, M. A. T. M., \& Ismail, F. Z. (2018). Tawjih Al-Qira'at Based on Inscription, Language, and Unusual Modes of Recitation According to Ibn Zanjalah. International Journal of Academic Research in Business and Social Sciences, 8(10), 362-370.

Abdelgelil, M. F. M., Daud, N. B., Omar, N. B., Ismail, F. Z. B., \& Wahab, A. H. B. A. (2018). Taujeeh Al-Qira'at Using Qur'an, Hadith and Poetry according to Ibn Zanjalah. International Journal of Academic Research in Business and Social Sciences, 8(10), 371-379.

Abdelgelil, M. F. M., Hasan, A. F., Yusoh, F., El khayat, M. H. M., Razali, M. A., Ismail, F. Z., \& Ab Rashid, R. (2021). Correlation Between Irregular Qiraat And Arabic Linguistics In The Quranic Tafseer Book By Al-Razi. International Journal of Academic Research in Business and Social Sciences, 11(7), 1632-1639.

Abdelgelil, M. F. M., Hasan, A. F., Yusoh, F., Ismail, F. Z., Ab Rashid, R., Ab Aziz, N. S., Hassan, A. (2021). The Impact of Irregular Qiraat on Arabic Semantics and Dialects. International Journal of Academic Research in Business and Social Sciences, 11(7), 1672-1676.

Abdelgelil, M. F. M., Hasan. A. F., Yusoh, F., El khayat, M. H. M., Razali, M. A., Hassan, A., Ab Aziz, N. S. (2021). Arabic Syntactic Rules with Reference to Quranic Qurra. International Journal of Academic Research in Business and Social Sciences, 11(7), 1707-1711.

Abdelgelil, M. F. M., Musolin, M. H., Serour, R. O. H., Abdullah, M. S., \& Noor, M. N. M. (2018). Law and Moral Values in the Holy Quran. International Journal of Academic Research in Business and Social Sciences, 8(11), 445-451.

Alfarra', Y. B. Z. (1990), Ma'ani Alquran. Tahqiq: 'Ahmad Yusuf Alnajati, Muhammad Ali Alnajjar, Aabdulfattah 'Isma'eil Alshalabi, Alqahirah: Dar Almisriyah Lilta'alif Waltarjamah. 
Altabari, M. B. J. (2000). Jami'e Albayan Fi Ta'wil Alquran. Tahqiq: 'Ahmad Muhammad Shakir, Bayrut: Mu'asasat Alrisalah.

Altha'labi, 'A. B. M. (2002). Alkashf Walbayan 'An Tafsir Alquran. Tahqiq: Al'Imam 'Abi Muhammad Bin 'Ashur. Beirut: Dar 'Ihya' Alturath Al'arabi.

Ibn Hanbal, 'A. B. M. (2010). Alrad 'Ala Aljahamiah Walzanadiqah. Tahqiq: Sabri Salamah Shahin. Alriyadz: Dar Althabat.

Ibn Qutaybah, A. B. M. (2002). Ta'wil Mushkil Alquran. Tahqiq: Ibrahim Shamsuddin, Beirut: Dar Alkutub Al'Elmiyah. 